\title{
Social determinants of health: poverty, national infrastructure and investment
}

\author{
Nathan T Douthit, ${ }^{1}$ Haimanot Kasahun Alemu ${ }^{2}$
}

\begin{abstract}
${ }^{1}$ Medical School for International Health, Ben Gurion University, Be'er Sheva, Israel

${ }^{2}$ Department of Oncology, Addis Ababa University Tinkur Abessa Hospital, Addis Ababa, Ethiopia

Correspondence to Dr Nathan T Douthit, ntdouthit@gmail.com
\end{abstract}

Accepted 7 June 2016

\section{SUMMARY}

This case presentation of a 19-year-old Ethiopian woman diagnosed with nasopharyngeal carcinoma reveals the barriers the patient has to medical treatment, including poverty and a lack of national infrastructure. The patient lives a life of poverty, and the outcome of her illness is a result of her being unable to overcome barriers to accessing health care due to inability to afford transport, lodging and treatment. In this case, the patient's vulnerability to disease due to her poverty is not overcome because of lack of infrastructure. The infrastructure fails to develop because of inadequate investment and other delays in building. The end result is that the patient is vulnerable to disease. Her disease process impacts her family and their contribution to Ethiopia's development.

\section{CASE PRESENTATION}

The patient is a 19 -year-old Ethiopian woman from a rural area near Gondar. She lives 6 hours by bus from the University of Gondar Hospital, the nearest public hospital. She is one of six children. Her parents are farmers, and have always lived in poverty. Their estimated income is $\sim 3 \mathrm{USD} /$ day. The patient was married and quickly divorced twice at young ages (5 and 12 years) in order to help relieve the financial burden of her family.

When she was 16 years old, she was referred from the health centre in her area to the University of Gondar Hospital, due to swelling of her left submandibular region. She received a biopsy but missed the follow-up appointment to see the results -it had been scheduled for 2 weeks later during the harvest days and the girl's father needed her help. Her symptoms worsened, and she left school due to difficulty concentrating from headache, greater swelling and discomfort when swallowing. Her younger sister also discontinued her education in order to care for her. The girl's poverty prevented her presentation to medical care as she could not afford bus fare and feared she would not be able to pay for the care when she arrived. She turned to the traditional Ethiopian medicine of holy water as a treatment for her disease. Over 2 years later, she returned to the hospital after recurrent emesis for 3 weeks with episodes of blood-tinged vomit. Biopsy was performed, and the patient was diagnosed with metastatic nasopharyngeal carcinoma. The doctors recommended a treatment regimen of Cisplatin and 5-FU (at a cost of $\sim$ US $\$ 75$ per cycle); however, those drugs were not available in Gondar at the time and would have to be brought from Black Lion Hospital in Addis
Ababa. There was a possibility the government would provide the drugs at no charge in Addis Ababa, but the patient could not afford the transportation fees. Her doctors also thought it likely that she would need radiotherapy, which was available only in Addis Ababa. The girl left the hospital as access to oncological care and further diagnostic testing was not possible due to distance and financial constraints.

The girl's symptoms worsened, and she returned again 4 months later. Physical examination showed a $10 \times 10 \mathrm{~cm}$ mass on the left side of her neck with a smaller $2 \times 2 \mathrm{~cm}$ mass below it. At that time, a general practitioner in the oncology ward at University of Gondar Hospital was in Addis Ababa, and she arranged for transport of the drugs from a public pharmacy and personally transported them to Gondar where the patient was hospitalised. The drugs were provided at no charge by the government due to the patient's evidence of financial need. The patient received an abrogated round of chemotherapy due to insufficient drugs, and responded well. The radiology department also carried out the imaging at no charge due to the patient's poverty. CT revealed a $5.3 \times 2.8 \mathrm{~cm}$ nasopharyngeal enhancing mass extending to the first cervical canal space and compressing the spinal cord. The left carotid artery and jugular vein were occluded by the mass. Additional chemoradiotherapy was recommended, and the patient's father said he would find some way to raise money for travel and medicine. However, on return home, he found himself unable to do so. This was due to many factors, as poor harvest returns plagued his farm and recently the family's few cows had been stolen; also, the patient's father found himself embroiled in a family feud that made him unable to leave the home and unable to try to find alternative methods of raising money for his daughter's transport and treatment.

Currently, one week after her final admission, the patient is uncertain from where her treatment will come, if at all. A foreign oncologist who staffs University of Gondar Hospital has travelled to Addis Ababa for other business and will discuss her case with the doctors at Black Lion Hospital. It is possible that a sufficient number of other patients will not require the calculated dose of these drugs at University of Gondar Hospital and will donate them to this patient in order to pool the medicine for treatment. However, the only way the patient will be guaranteed full, continuous treatment will be for her family to find financial resources for travel, living and providing care in Addis Ababa. 
It has been reported that Ethiopian women with cervical cancer who travelled to Addis Ababa for radiotherapy spent an average amount of US\$378.8 on treatment and living expenses. ${ }^{1}$ While the patient may be in severe enough poverty to qualify for free treatment, she will have to find money for her living and travel expenses. That amount represents an unattainable goal since the patient and her sister are even unsure of where they will find the money to pay for bus fare home, a cost equivalent to about US\$4 each.

\section{GLOBAL HEALTH PROBLEM LIST}

This patient's medical problem is further complicated by the cycle of

- Poverty;

- Lack of treatment options and social infrastructure;

- Failure to invest in social infrastructure;

- The effects of disease on a vulnerable population.

\section{GLOBAL HEALTH PROBLEM ANALYSIS Poverty}

In 2010, the United Nations Development Program refined the concept of the human development index. ${ }^{2}$ The intent was to shift focus away from income only and turn instead to the capability to develop. It was based on three core capabilities: to survive, measured by life expectancy at birth; to be knowledgeable, measured by mean and expected years of schooling; and to access a decent standard of living, measured by gross national income per capita. ${ }^{3}$ In 2015, Ethiopia ranked 174 out of 188 in the UNDP Human Development Index, making the country one of the poorest in Sub-Saharan Africa. The UNDP also reports that $88.2 \%$ of the population are multidimensionally poor based on health, education and standard of living metrics. ${ }^{4}$

The problem of poverty is a global one. The World Bank classifies $~ 3.5$ billion people as living in low income (LIC) or low-middle-income countries (LMIC) in areas such as Asia, Eastern Europe, Africa, South and Central America, and the Pacific Rim. ${ }^{5}$ The low income of these countries certainly has adverse outcomes on health. ${ }^{6-8}$ The poor are vulnerable because they have no means to provide for their own health. ${ }^{6}$ Also, a higher burden of poverty has been shown to tend towards less public spending on healthcare. ${ }^{9}$ This shows that poverty exacerbates poor health and vice versa. ${ }^{10-13}$

Poverty has many different roots including a history of 'pernicious institutional dynamics' such as slavery or colonisation, lack of natural resources, government corruption or armed conflict. ${ }^{14}{ }^{15}$ Because these populations are vulnerable to attacks of disease as a result of their poverty, a strong societal infrastructure is necessary to ensure their ability to access healthcare at times of disease and personal disaster. According the Asian Development Bank, "Infrastructure is synonymous with economic development". ${ }^{16}$ To relieve poverty and impact health, this infrastructure must include education, transport and economic opportunity. ${ }^{17}$ From independence in 1962 to the mid-1980s, Uganda suffered from political turmoil, conflict and economic mismanagement. The government increased their public expenditure (in constant 1997 prices) from 264 billion shillings in 1982 to 1043 billion shillings in 1999. This is an annual growth rate of more than $8.4 \%$. They increased their spending on education as a per cent of government expenditure from $20.07 \%$ to $35.5 \%$. They spent $6.8 \%$ of expenditure on health, well above the African average of $4 \%$ in 1999, and their absolute spending on health increased more than threefold. As a result of road building and maintenance programmes, the average distance of a household from a tarred road fell from
$32 \mathrm{~km}$ in 1997 to $22 \mathrm{~km}$ in $1999 .{ }^{18}$ By 2003, 27\% of the rural population of Uganda lived within $2 \mathrm{~km}$ of an all-season road and the country has continued to invest in transportation. ${ }^{19}$ In 1996, 2.7 million people were enrolled in school, which grew to 6.6 million people by 1999 and reached 8.4 million by $2010 .{ }^{18}{ }^{20}$ In $2008-2012,92.5 \%$ of the male population was enrolled in a primary school, compared to $95.2 \%$ of the female population. ${ }^{21}$ These efforts resulted in a decrease in poverty, from $56 \%$ to $35 \%$, from 1992 to 1999 , which further decreased to $19.5 \%$ in $2012 .{ }^{18}{ }^{21}$ Although a mismanaged healthcare system did not allow for growth in many health indicators during that time frame, the alleviation of poverty has led to recent improvement in their health indicators including a $53 \%$ reduction in mortality of those under 5 years of age, since $2000 .^{22} 23$ Although the spending habits of the Ugandan government have changed in recent years, their example from a generation ago shows that this type of public expenditure can be very helpful in combating poverty and generating opportunity for economic advancement.

\section{Lack of treatment options and social infrastructure}

Without the aforementioned infrastructure, however, the poor will be vulnerable to poor health, especially as the burden of disease changes in low-income countries. Non-communicable disease in general and cancer in particular are on the rise in the developing world. Roughly four of five deaths from noncommunicable disease occurred in the developing world in $2008 .^{24}$ By 2020 , mortality rates from cancer are expected to increase approximately fivefold in the same population. ${ }^{25}$ By 2030, non-communicable diseases are expected to account for one-half of the disease burden in low-income countries. ${ }^{26}$ This is largely due to an ageing population and adoption of a Western lifestyle including decreased physical activity, poor diet and increased tobacco usage, in the developing world. ${ }^{24-27}$ This patient's illness reveals the weakness of the existing infrastructure and underpreparedness of the developing world to deal with non-communicable disease.

With a growing population of over 90 million, Ethiopia only has one cancer referral centre, Black Lion Hospital. It is a 600-bed institution with 18 beds allocated for cancer treatment. The hospital is located in the capital, Addis Ababa, and employs 201 physicians. Of these, there are two haematologists, four medical oncologists, four radiotherapists, two surgical oncologists, one paediatric oncologist and three palliative pain specialists. There is one CT scanner, one MRI and insufficient access to radiotherapy and other treatments. Long waiting periods and increasing demand for services also affect the centre. The hospital saw 2000 adults with cancer in 2010. The most common cases treated are breast, cervical and head and neck cancers. Owing to the high need, the wait for oncological consultation is estimated to be over 6 months. ${ }^{28}$ Patients must provide for their own transportation, lodging and food, and pay for treatment in Addis Ababa, which can be prohibitively expensive. ${ }^{1}$ Ethiopia is not alone. For radiotherapy, only 4 of 139 LICs and LMICs have adequate units. Of those countries, 55 have no radiation therapy facilities. ${ }^{29}$ Another study revealed that, of 56 African countries, none have adequate cancer screening; 49 have cancer pathology services and 20 have radiotherapy services. ${ }^{30}$

Many developing countries still require direct payments from patients at the time of service, which can prohibit the poor from using the service and bankrupt them even further when they finally seek medical treatment at the last moment, as in the case of the patient mentioned above. ${ }^{31}$ Also, the lack of transportation and housing options can be prohibitive for patients. ${ }^{1}$ 
Social factors such as poverty, inadequate transport, educational deficits and lack of access place patients such as the girl described above at a disadvantage in health. Investment in healthcare and societal infrastructure can overcome these issues. ${ }^{32}$ It has been shown that access to health is improved by road infrastructure and that education improves health, and, additionally, that agricultural research and development can also create a healthier population. ${ }^{7} 1633-36$

While not a direct comparison to our case, the Chinese example can show that infrastructure building and health care are correlated. In 1985, China was 9 years removed from the turmoil of the cultural revolution. There were over 100 million Chinese living in poverty. Infrastructure including roads and agricultural research was weak, education was neglected and the poverty level was increasing. To address the issue of their infrastructure, the Chinese government built over $400000 \mathrm{~km}$ of road, provided phone access to 16 million rural inhabitants and saw the amount of electricity consumed in rural areas rise from 18 billion to 180 billion kilowatts between 1975 and 1997. They also invested in agricultural research and mandated 9 years of education. ${ }^{37}$ These efforts were shown to reduce income inequality and decrease rural poverty. ${ }^{38} 39$ China has also seen improvement in health outcomes. By 2004, they had increased life expectancy to 71 years, and seen maternal, infant and under five mortality rates drop to $0.05 \%, 1.8 \%$ and $2.0 \%$, respectively. ${ }^{40}$ More recently, cancer treatment has also improved. In 1986, the Office of Cancer Prevention and Control was established and successfully made efforts to reduce mortality among vulnerable populations, specifically in rural areas. In 2002, a national cancer registry was established in order to provide research and focus on cancer control efforts. ${ }^{41}$ The second stage of the national cancer control programme has succeeded in decreasing smoking prevalence. ${ }^{42}$ China now has more than 200 cancer hospitals, 30 tertiary-level hospitals for cancer and many general hospitals with cancer departments. There are 25600 oncologists, and the number of oncology beds doubled between 2005 and 2010, now standing at 134 395. While still inadequate, China is scaling up its cancer treatment centres, announcing a recent plan to greatly increase the number of healthcare delivery facilities throughout the country. China is also making efforts to decrease the price of antineoplastic drugs and increase the equity of its healthcare system in order to further decrease disparities. ${ }^{41}$ The example of China shows that good health for a poor population can be achieved by investment in infrastructure.

\section{Failure to invest in infrastructure}

Despite agreeing to the Abuja declaration in 2001, however, less than 10 African countries budget the targeted $15 \%$ of their spending on health. ${ }^{43}$ In 2015 , it was shown that LICs and LMICs spend significantly less of their already limited gross domestic products (GDPs) on healthcare $(10.8 \%$ and $10.2 \%$, respectively) than upper-middle-income or high-income countries do of their higher GDPs $(12.5 \%$ and $13.5 \%$, respectively). This brings the out-of-pocket expenditure to a prohibitively high level $(42.3 \%$ and $40.4 \%$ for LICs and LMICs, respectively). It is also shown that healthcare spending leading to impoverishment is almost entirely concentrated in the lowestspending quintile of countries. This quintile also contains a high median $41.2 \%$ of people who self-reported no spending on healthcare in a given year. ${ }^{44}$ Despite improvement in public health spending in recent years, it was, respectively, still only $37.3 \%$ and $38.3 \%$ of total amount spent on health by LICs and LMICs (compared to $55.6 \%$ and $68.3 \%$ by upper-middle income countries and high-income countries, respectively). These numbers are despite the fact that net official developmental assistance doubled to low-income countries over the same period. ${ }^{45}$ Reasons for the lack of investment in these countries include poor planning, armed conflict and high-level corruption.

Many of these countries do not plan to allot public spending in health services, equity programmes and other social goods. Of 22 LICs reviewed, less than $1 / 3$ had actionable plans regarding employment, equality in education, gender equality in political representation and violence, maternal health and HIV/AIDS health, natural resource protection, and governance emphasising human rights and minority rights. ${ }^{46}$ The WHO showed that,

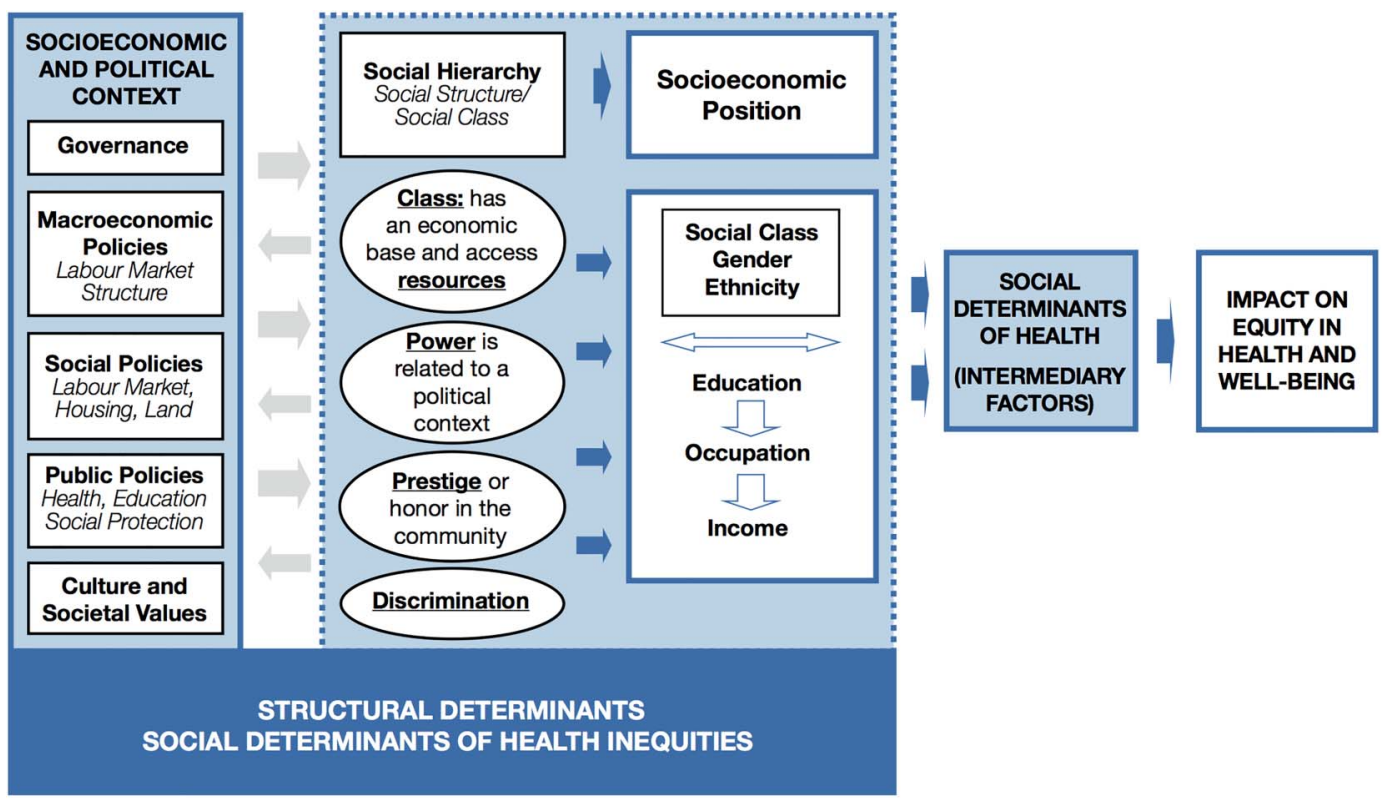

Figure 1 Reprinted from A Conceptual Framework for Action on the Social Determinants of Health: Social Determinants of Health Discussion Paper 2, Solar 0, Irwin A. Chapter 5-CSDH Conceptual Framework, 35, Copyright (2010). 
despite improvement, low-income countries spend less of their GDPs on education compared to other country groups $(4.1 \%$ compared to $5.4 \%$ in high-income countries). ${ }^{45}$

While not currently the case in Ethiopia, armed conflict is a concern for many countries in the region. It has been shown that "Two thirds of all armed conflicts take place in African countries with the highest poverty rates.... [T] he lower the GDP per capita in a country, the higher the likelihood of armed conflict". This cycle is prevalent in Africa, which has a recent history of economic deprivation and armed conflict in many states, making it vulnerable to sudden economic shocks. ${ }^{47} 48$ Half of the world's poor will live in states characterised by fragility, conflict and violence, by the year $2030 .{ }^{49}$ Armed conflict results in a failure to invest a nation's public infrastructure, which includes education, disaster relief planning and health. ${ }^{50}$ It can also devastate a nation's physical capital and human resources. ${ }^{51-53}$ These effects can have ramifications for over a decade following conflict. ${ }^{48} 5455$ Reasons for conflict are varied but linked to common problems in developing countries. 5356

Another problem is rampant high-level corruption. According to the UNDP, "All too often, even when resources are allocated, they do not reach the actual beneficiaries because of a lack of accountability in the distribution or use of funds". ${ }^{51}$ It has been stated that $20-40 \%$ of official development assistance is stolen through high-level corruption. ${ }^{57}$ The African Union reported, in 2011, that 25\% of the GDP of African states is lost to corruption every year. ${ }^{58}$ Higher levels of corruption have been linked to illiteracy, lack of access to clean drinking water and deficiencies in other basic public services. ${ }^{59}$

\section{The effects of disease on a vulnerable population}

In the case mentioned above, the patient is seen as already vulnerable due to her poverty, lack of access to care and lack of education in her family. As her disease begins, however, she is unable to gain access to treatment, due to poor infrastructure including lack of educational and economic opportunity, lack of transport and inadequacy of 'safety net' options for the poor. After that, she is required to stop school, which further depletes her opportunity for economic advancement. Later, she is unable to assist in her family's labour, decreasing their agricultural production and the contribution of her family to the economy. The disease also removes her sister from education, drives her parents further into poverty and removes opportunity for sustainable development within the country of Ethiopia. This type of process can risk security for other nations and can diminish international trade, and may impose an even heavier burden on the poor populations. ${ }^{60} 61$

Ethiopia is making efforts to decrease poverty, to strengthen infrastructure and to reallocate their public spending. They have invested in public services such as safety nets, roads and agricultural production. ${ }^{62}$ The Black Lion Hospital has partnered with Norwegian and American universities in order to establish an oncology training programme to increase the number of oncologists in Ethiopia. ${ }^{63}$ This partnership is attempting to increase the number of doctors produced by the country, to strengthen the health system. ${ }^{64}$ They have begun pilot programmes for community based and social health insurance. ${ }^{6566}$ These interventions are positive steps towards protecting patients, such as the girl described above.

Social determinants of health clearly impact health equity (see figure 1). ${ }^{67}$ Our patient is vulnerable to the effects of ill health due to her social status. The Declaration of Alma Ata reminds us that health is a state of "complete physical, mental and social wellbeing", and that the "promotion and protection of the health of people is essential to sustained economic and social development and contributes to a better quality of life and world peace". ${ }^{68}$ To break the cycle seen in the patient described above, systems of transparent, honest and democratic governance must be created in which all the people have the voice to create a political will to improve their situation, including both, their social determinants of health and delivery of healthcare. ${ }^{506869}$ The declaration's ninth point emphasises that "All countries should cooperate in a spirit of partnership and service to ensure primary health care for all people since the attainment of health by people in any one country directly concerns and benefits every other country". ${ }^{68}$ Physicians must advocate for the resolution of social problems that lead to poor health as well as be involved in the delivery of healthcare.

\section{Patient's perspective}

I understand the disease is not from God or Satan, but is something that happens to all people, I was just the unfortunate one to get it. I strongly desire to continue medical treatment, but am aware that that may not be possible. I want to know if it will be, because the best use of my time if not receiving medical treatment would be in holy water. Thank you for your willingness to tell my story, and I hope that perhaps it will help other people in my position.

\section{Learning points}

- Poverty creates vulnerable patient populations in the developing world.

- These populations are made even more instable by fragile or non-existent infrastructures in their developing countries.

- The lack of investment in these global populations (exacerbated in some locations by combinations of poor planning, armed conflict, natural disaster and corruption) increases their risk for a catastrophic outcome.

- This catastrophic outcome is bad for the patient, their family, their nation and the global community.

- Steps must be taken to decrease poverty, strengthen infrastructure and invest in people in order to avoid these catastrophes.

Acknowledgements Nathan Douthit, as a student at Ben Gurion University Medical School for International Health, completed a global health and medicine elective at the University of Gondar Hospital, and would like to thank the staff for its hospitality during his stay. Special thanks to Dr Ephrem Tafesse and the University of Gondar Hospital Oncology Department as well as Dr Ermias Diro and Dr Hailemariam Alemu of the Internal Medicine Department. The authors would like to gratefully acknowledge Dr Richard Deckelbaum of Columbia University Medical Center, who is a Senior Advisor on Global Health, MSIH, for his help in preparing this manuscript.

Contributors We, NTD and HKA, take responsibility for planning, conducting and reporting the work.

Competing interests None declared.

Patient consent Obtained.

Provenance and peer review Not commissioned; externally peer reviewed. 


\section{REFERENCES}

1 Tadesse SK. Socio-economic and cultural vulnerabilities to cervical cancer and challenges faced by patients attending care at Tikur Anbessa Hospital: a cross sectional and qualitative study. BMC Womens Health 2015;15:75.

2 Klugman J. Human development report 2010: the real wealth of nations: pathways to human development. Palgrave Macmillan, 2010.

3 Fukuda-Parr S. The human poverty index: a multidimensional measure. In: Ehrenpreis D, ed. What is poverty concepts and measures? Brazil: United Nations Development Program International Poverty Center, 2006;7-9.

4 UNDP. Human development report 2015. Ethiopia. United Nations Development Programme, 2013:2-6.

5 World Bank. Country and Lending Groups. http://data.worldbank.org/about/ country-and-lending-groups (accessed 27 Jan 2016).

6 World Bank. Poverty and Health. http://www.worldbank.org/en/topic/health/brief/ poverty-health (accessed 27 Jan 2016).

7 Douthit N, Kiv S, Dwolatzky T, et al. Exposing some important barriers to health care access in the rural USA. Public Health 2015;129:611-20.

8 Cambanis A, Yassin MA, Ramsay A, et al. Rural poverty and delayed presentation to tuberculosis services in Ethiopia. Trop Med Int Health 2005;10:330-5.

9 Xu K, Saksena P, Holly A. The determinants of health expenditure. World Health Organization, 2011.

10 Sachs JD, Warner AM. Sources of slow growth in African economies. J Afr Econ 1997;6:335-76.

11 Acemoglu D, Johnson S. Disease and development: the effect of life expectancy on economic growth. National Bureau of Economic Research, 2006.

12 Weil DN. Accounting for the effect of health on economic growth. National Bureau of Economic Research, 2005.

13 Ashraf QH, Lester A, Weil DN. When does improving health raise GDP? National Bureau of Economic Research, 2008.

14 Acemoglu D, Robinson JA. Why is Africa Poor?. Economic History of Developing Regions 2010;25(1):21-50.

15 Jha P. Causes of poverty in developing countries. Barbieri-Masini E ed. Quality of Human Resources: Gender and Indigenous Peoples. 1st edn. USA: EOLSS, 2008:35-71.

16 Asian Development Bank. Infrastructure for Supporting Inclusive Growth and Poverty Reduction in Asia. Philippines: ADB, 2012. http://www.adb.org/sites/default/files/ publication/29823/infrastructure-supporting-inclusive-growth.pdf (accessed 31 Jan 2016).

17 Adam Smith International. Measuring and maximising value for money in infrastructure programs. UK: UKAid, 2012. https://www.gov.uk/government/uploads/ system/uploads/attachment_data/file/194319/measure-maximize-VfM-infrastructure. pdf (accessed 31 Jan 2016).

18 Fan S, Zhang X. Public expenditure, growth and poverty reduction in rural Uganda. Afr Dev Rev 2008;20:466-96.

19 The World Bank. Rural Access Index. http://data.worldbank.org/data-catalog/ rural-access-index (accessed 29 May 2016).

20 The World Bank. Education Statistics Uganda. https://knoema.com/WBEdStats 2014Apr/education-statistics-world-bank-april-2014?country=1002180-uganda (accessed 29 May 2016).

21 The World Bank. Uganda: Data. http://data.worldbank.org/country/uganda (accessed 29 May 2016).

22 World Health Organization. Uganda. Country Cooperation Strategy at a Glance. 2014.

23 Baguma, Raymond. Uganda's health indicators improve. http://www.newvision.co. ug/new_vision/news/1305440/ugandas-health-indicators-improve (accessed 31 Jan 2016).

24 World Health Organization. Global status report on noncommunicable diseases. Geneva: World Health Organization, 2011.

25 Rastogi T, Hildesheim A, Sinha R. Opportunities for cancer epidemiology in developing countries. Nat Rev Cancer 2004;4:909-17.

26 World Health Organization. Global Health and Aging. USA: WHO, 2011. http:/l www.who.int/ageing/publications/global_health.pdf (accessed 31 Jan 2016).

27 United Nations, Department of Economic and Social Affairs, Population Division (2013). World Population Ageing 2013. ST/ESA/SER.A/348.

28 Woldeamanuel YW, Girma B, Teklu AM. Cancer in Ethiopia. Lancet Oncol 2013;14:289-90.

29 Datta NR, Samiei M, Bodis S. Radiation therapy infrastructure and human resources in low-and middle-income countries: present status and projections for 2020. Int J Radiat Oncol Biol Phys 2014;89:448-57.

30 Kanavos P. The rising burden of cancer in the developing world. Ann Oncol 2006;17(suppl 8):viii15-23.

31 Moreno-Serra R, Smith PC. Does progress towards universal health coverage improve population health? Lancet 2012;380:917-23.

32 Morhason-Bello IO, Odedina F, Rebbeck TR, et al. Challenges and opportunities in cancer control in Africa: a perspective from the African Organisation for Research and Training in Cancer. Lancet Oncol 2013;14:e142-51.

33 Von Braun J. Rural-urban linkages for growth, employment, and poverty reduction. Ethiopian Economic Association Fifth International Conference on the Ethiopian
Economy. Washington DC, USA: International Food Policy Research Institute, 7 June 2007:7-9.

34 Reinikka R, Collier P, eds. Uganda's recovery: the role of farms, firms, and government. World Bank Publications, 2001.

35 Fan S, Hazell P, Thorat S. Government spending, growth and poverty in rural India. Am J Agric Econ 2000;82:1038-51.

36 International Labour Association. Infrastructrure, Poverty Reduction and Jobs. http:/l www.ilo.org/global/docs/WCMS_099513/lang--en/index.htm (accessed 31 Jan 2016).

37 Fan S, Zhang L, Zhang X. Growth, inequality, and poverty in rural China: The role of public investments. Intl Food Policy Res Inst 2002;125:18-24.

38 Mundial B. China: Infrastructure, Growth, and Poverty Reduction, Shanghai Poverty Conference: Case Study Summary.

39 Duncan T. Findings from studies of poverty impacts of road projects. Asian Development Bank, 2007.

40 World Health Organization. China: health, poverty and economic development. Beijing: Office of the WHO Representative in China, and Social Development Department of the China State Council Development Research Centre, 2005.

41 Goss PE, Strasser-Weippl K, Lee-Bychkovsky BL, et al. Challenges to effective cancer control in China, India, and Russia. Lancet Oncol 2014;15:489-538.

42 Wang L, Kong L, Wu F, et al. Preventing chronic diseases in China. Lancet 2005;366:1821-4.

43 Awosusi B. Universal health coverage in Africa: time to step up advocacy. http:// globalhealth.thelancet.com/2014/10/24/universal-health-coverage-africa-timestep-advocacy (accessed 27 Jan 2016).

44 World Health Organization. Tracking universal health coverage: first global monitoring report. Geneva: WHO, 2015.

45 Rahman M, Khan TI, Sadique MZ. Public Expenditure Trends in Low-Income Countries in the Post-MDG Context. European Report on Development (ERD). 2015.

46 Fukuda-Parr S. Are the MDGs priority in development strategies and aid programmes? Only few are!. Working Paper, International Poverty Centre, 2008.

47 Paffenholz T, Underdevelopment and Armed Conflict: Making Sense of the Debates. Paper presented at the International Studies Annual Convention San Francisco, 26-29 March 2008. Geneva: Centre for Conflict, Peace and Development, Graduate Institute of International and Development Studies.

48 Collier P, Hoeffler A. Aid, policy, and growth in post-conflict economies. Ina Joint World Bank-IMF Seminar. Washington DC, 2002.

49 World Bank. Fragility, Conflict and Violence. http://www.worldbank.org/en/topic/ fragilityconflictviolence/overview (accessed 31 Jan 2016).

50 Gupta S, Clements B, Bhattacharya R, et al. Fiscal consequences of armed conflict and terrorism in low-and middle-income countries. Eur J Polit Econ 2004;20403-21.

51 UNDP. Beyond the midpoint: achieving the millenium development goals. New York: United Nations, 2010.

52 Ibáñez AM, Moya A. Do conflicts create poverty traps? Asset losses and recovery for displaced households in Colombia. In: Di Tella R, Edwards S, Schargrodsky E, eds. The economics of crime: lessons for and from Latin America. University of Chicago Press, 2010:137-72.

53 Stewart F, Holdstock D, Jarquin A. Root causes of violent conflict in developing countries/Commentary. Br Med J 2002;324:342.

54 Bakrania S, Lucas B. The Impact of the Financial Crisis on Conflict and State Fragility in Africa. Emerging Issues Paper commissioned by AusAID, Governance and Social Development Resource Centre (GSDRC). University of Birmingham, 2009, http://www.gsdrc.org/docs/open/EIRS6.pd

55 Bureau for Economic Growth, Agriculture and Trade. A Guide to economic growth in post-conflict countries. Washington DC: USAID, 2009. http://pdf.usaid.gov/pdf_ docs/Pnad0408.pdf (accessed 31 Jan 2016).

56 Regehr E. Armed conflict: trends and drivers. Vancouver: The Simons Foundation, 2011.

57 Baker RW. Capitalism's achilles heel: dirty money and how to renew the free market system. Hoboken, NJ: John Wiley \& Sons, 2005.

58 Joiner J. Opening Statement at the Consultations Between National Anti-Corruption Bodies, AUC and Recs on Implemenation and Harmonization of the Continental and Regional Standards and Legislation on Anti-Corruption. Speech presented at; 2011, Bamako, Mali.

59 Transparency International. Corruptions perception index 2015. Transparency International, 2016. http://www.transparency.org/whatwedo/publication/the_anti_ corrupti\%20on_catalyst_realising_the_mdgs_by_2015 (accessed 27 Jan 2015).

60 Donaldson L, Banatvala N. Health is global: proposals for a UK Government-wide strategy. Lancet 2007;369:857-61.

61 Russell S. The economic burden of illness for households in developing countries: a review of studies focusing on malaria, tuberculosis, and human immunodeficiency virus/acquired immunodeficiency syndrome. Am J Trop Med Hyg 2004;71(2 Suppl):147-55

62 Hill RV, Tsehaye E. Growth, Safety Nets and Poverty: Assessing Progress in Ethiopia from 1996 to 2011. Background paper for the Ethiopia Poverty Assessment. Washington, DC: World Bank, 2014.

63 Pyle D, Daly N. ASCO and the conquer cancer foundation: a global oncology community sharing knowledge to improve patient care. Cancer Control 2013:147. 


\section{Global health}

64 IRIN Africa. ETHIOPIA: Surge of doctors to strengthen health system. http://www. irinnews.org/report/96101/ethiopia-surge-of-doctors-to-strengthen-health-system (accessed 27 Jan 2016).

65 Ali EE. Health care financing in Ethiopia: implications on access to essential medicines. Value in Health Reg Issues 2014;4:37-40.

66 USAID. Ethiopia's Community-based Health Insurance: A Step on the Road to Universal Health Coverage. Health Finance and Governance, 2014.

pdf.usaid.gov/pdf_docs/PA00KDXT.pdf (accessed 27 Jan 2015).
67 Solar 0, Irwin A. A conceptual framework for action on the social determinants of health. Social Determinants of Health Discussion. Paper 2 (Policy and Practice).

68 World Health Organization. Declaration of Alma Ata. http://www.euro.who.int/en/ publications/policy-documents/declaration-of-alma-ata,-1978 (accessed 31 Jan 2016).

69 Olken BA, Pande R. Corruption in developing countries. National Bureau of Economic Research, 2011.

Copyright 2016 BMJ Publishing Group. All rights reserved. For permission to reuse any of this content visit http://group.bmj.com/group/rights-licensing/permissions.

BMJ Case Report Fellows may re-use this article for personal use and teaching without any further permission.

Become a Fellow of BMJ Case Reports today and you can:

- Submit as many cases as you like

- Enjoy fast sympathetic peer review and rapid publication of accepted articles

- Access all the published articles

- Re-use any of the published material for personal use and teaching without further permission

For information on Institutional Fellowships contact consortiasales@bmjgroup.com

Visit casereports.bmj.com for more articles like this and to become a Fellow 